\title{
MOMENT RESISTANCE OF I-SECTION END-PLATE ROOF GIRDER SPLICES; A CASE STUDY
}

\author{
K. ŻÓŁTOWSKI ${ }^{1}$, P. KALITOWSKI ${ }^{2}$
}

\begin{abstract}
This article deals with the problem of determining the resistance of end-plate connections. A nonlinear FEM model of the joint was constructed in order to predict its carrying capacity. A standard code procedure was done as well. The analyses have been done to assess atypical end-plate joints designed and constructed as a part of roof structures.
\end{abstract}

Keywords: non-preloaded end-plate joint, bending connection, FEM analysis, sports hall roof

\section{INTRODUCTION}

A case study of bending end-plate joints has been done alongside the independent structural analysis of the roof structure of the Leszek Blanik sports hall in Gdansk (under construction). The steel structure of the roof is of simple design, as a steel grid with main beams of I variable height welded profile (fig. 1a). The span of these simply-supported beams is $L=34.82 \mathrm{~m}$. Steel S355 was used.

The D and F category end-plate joints [1] of I-section elements are complicated to interpretation via principal mechanical rules. Specifically problematic is the prediction of the flow of forces between elements through joints and end-plates (not only from flange to flange). In result, it is difficult to define one universal procedure for determining end-plate connection resistance.

\footnotetext{
${ }^{1}$ DSc., PhD., Eng., prof. of Gdansk University of Technology, Faculty of Civil and Environmental Engineering, St. Gabriela Narutowicza 11/12, 80-233 Gdansk, Poland, e-mail: zoltowk@pg.gda.pl

${ }^{2}$ M., Eng., Gdansk University of Technology, Faculty of Civil and Environmental Engineering, St. Gabriela Narutowicza 11/12, 80-233 Gdansk, Poland,
} 
Polish Code [1] and Eurocode 3 [2] contain different procedures for determining resistance of bending end-plates beam splices. In the author's opinion, none of these can be universally applied to all cases, even if all imposed code conditions are fulfilled.

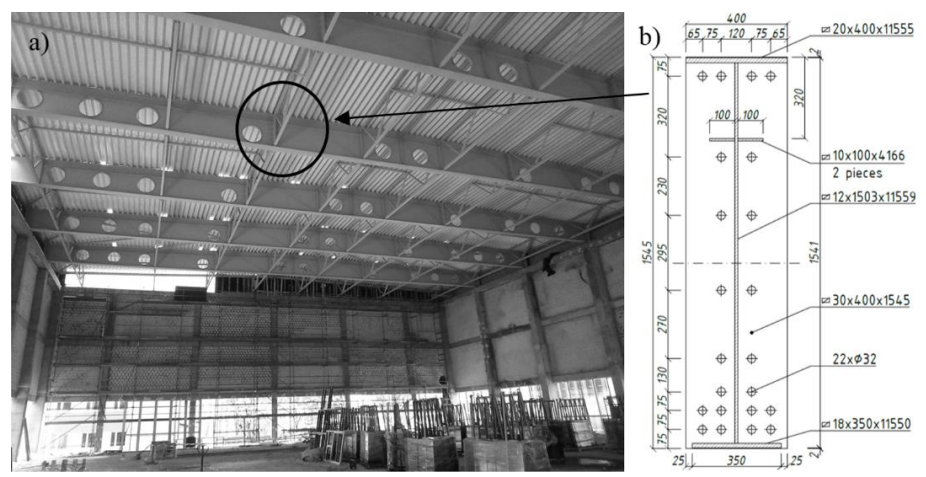

Figure 1. The analyzed joint: a) view of the roof of Blanik hall during construction with localization of splices, b) the cross-section of end-plate joints (own archive)

\section{THE DESIGN OF THE END-PLATE CONNECTION}

First, the work of the unitary girder had been analyzed. Results of the analysis confirmed that resistance potential of the main beams was correctly designed. Thus, it was decided to investigate the joints between parts of the girders. Three sections $(\mathrm{L}=11.58+12.06+11.58[\mathrm{~m}])$ were assembled at the building site with non-preloaded bolted connections (category D). In each joint 22 M30 bolts class 10.9 were used (fig. 1b). 30mm thick S355 end-plates were used. The positioning of the bolts' locations in the joint is shown in Figure 1b.

End-plate beam splices in bendings which connects I- or H-sections have a very complex static scheme. Further complication the matter is the existence of at least three basic schemes of failure (category D joints). Thus, in future design processes these ultimate limit states must be considered [3]:

- breakage of a bolt or punching of a bolt's head through a plate,

- yielding of an end-plate,

- strength of the welds which connect an end-plate with an element,

- yielding of a beam's web under tension [2]. 
If the resistance of a bending joint is determined by the above-specified failure models separately, it provides unreal and unsafe results. Thus, in general cases, resistance should be determined with mixed schemes of failure, however, this issue in analytical approach is quite difficult. Due to the multiplicity of the potential difficulties, the resistance of the joint was identified in three ways: according to PN-90/B-03200 [1], according to PN-EN 1993-1-8 [2], and via analysis of the 3D FEM models.

\section{Resistance aCCORding to Polish Code PN-90/B-03200}

The procedure of resistance identification according to [1] is based on the usage of tabulated coefficients, which specify the distribution of force between bolt rows. The coefficients were developed in the 1970's [1,4,5] in tensile tests of joints. The coefficient is the ratio of force in the bolt compared to the resistance of the bolt itself. Unfortunately the procedure described in [1] has a limited scope of application. The table with coefficients of force distribution contains only a few cases of bolt location for M20 and M24 bolts only. Additionally, a restriction of minimal thickness for end-plates is specified (Eq. (3.1)).

$$
t \geq t_{\min }=1,2 \sqrt{\frac{c \cdot S_{R t}}{b_{s} \cdot f_{d}}}
$$

where:

$\left(\mathrm{S}_{\mathrm{Rt}}\right.$ - the design bolt resistance, $\mathrm{f}_{\mathrm{d}}$ - the design strength of the end-plate, $\mathrm{c}$ - the distance between the edge of the hole and the weld or the beginning of the rounding, $b_{s}$ - the interaction width of the end-plate per one bolt).

Further limiting analysis is the requirement to consider at maximum three rows of bolts. If adducted conditions are met, Polish Code [1] allows the model to skip additional prying forces for parts of end-plates which are constrained on at least on two edges. Finally, the ultimate resistance of a $\mathrm{D}$ category end-plate beam splice in bending has the following form:

$$
M_{R j}=S_{R t} \sum_{i}^{k} m_{i} \cdot \omega_{i} \cdot y_{i}
$$

where: 
$\left(\mathrm{S}_{\mathrm{Rt}}\right.$ - the design bolt resistance, $\mathrm{k}$ - the number of rows included in the calculation, $\mathrm{m}_{\mathrm{i}}-$ the number of bolts in the i-th row, $\omega_{i}-$ the load distribution coefficient for the bolts in the i-th row, $y_{i}-$ the arm of force in bolts relative to the compression center).

For the considered joint, conditions dictated by [1] have not been met. Unfortunately the designer has used procedures from [1] only to predict joint resistance. Despite this, the authors, being aware the existing limits, have done calculations of joint resistance with the assumptions that: load distribution coefficients for bolts M30 are equal to those of M24 (factors for M30 do not exist), the bolt distribution exists on a scheme of 4-2-2 instead of 4-4-2 (used by designer), only three end rows of bolts exist. For this model to closely mimic reality the design joint resistance has been calculated as $M_{R j}=3200 \mathrm{kNm}$. Further analysis shows that it is in fact an overvalued result.

\section{RESistanCE ACCORDING TO EUROCODE PN-EN 1993-1-8}

In Eurocode [2], the resistance of an end-plate beam splice is determined as the resistance of the individual components: end-plates, plates of connected elements, welds, and bolts. Assuming that the external bolts in the second row (Fig. 1b) are not active (elaboration later in the article) the design joint resistance has been calculated as $M_{j, R d}=3400 \mathrm{kNm}$. Although a component method is significantly more complex than the procedure from [1] because it includes an analytical approach, different criteria, and three failure models of T-sub, it is still only an approximate method. According to [3] and [7], the reliability of the component method depends mainly on an end-plate's thickness and the location and class of the bolts. It has been noted that in nonpreloaded end-plate joints, normal strength bolts (4.6 or 5.6) are recommended [3]. This is because of the low ductility of the higher strength bolts required in D category joints. Additionally, in the case of class 4 webs in joints, the authors [3,7] recommend taking into account only the two bolt rows located closest to the tensioning flange. In the case of elements with class 3 webs, bolts from the next internal row can be included as well. The design resistance of the joint in question, calculated with only the first row equals $M_{j, R d}=2025 \mathrm{kNm}$. In the case of an additional row of bolts, the strength reaches a value of $M_{j, R d}=2987 \mathrm{kNm}$.

The general procedure for determining resistance in [2] is complex. On the basis of assumptions taken from [2] and the principles of mechanics, the authors of [3,7] created a simplified procedure. Unfortunately, the analyzed case does not meet the imposed requirements and the analyzed endplate connections have been calculated with the general procedure. 


\section{THE FEM MODEL OF THE END-PLATE BEAM SPLICE}

As mentioned previously, the calculated code values of resistance are not exactly appropriate for the problem considered here, and thus, the authors decided to create a numerical model of the joint. The model has been constructed in the FEM SOFiSTiK environment (Fig. 2). The authors have made the following assumptions: the moment resistance of the joint was analyzed, and the model was analyzed to obtain a distribution of forces in bolts. The first plasticization of bolts, local stress concentrations in the plates - in contact zone with bolts - were not analyzed, the nonlinear (geometric and material) volume model was applied, and symmetry of the joint was used. The cantilever scheme loaded with point bending moment was used. 8-nodal, volume elements with maximal dimensions of $6 \mathrm{~mm}$ were implemented for the plates in the joint. In the distance of $200 \mathrm{~mm}$ from the end-plate, a $500 \mathrm{~mm}$-long structure of the girder has been meshed with 4-nodal membrane elements. The end-plate and girder have been analyzed with elastic-plastic with a hardening model of S355 steel.

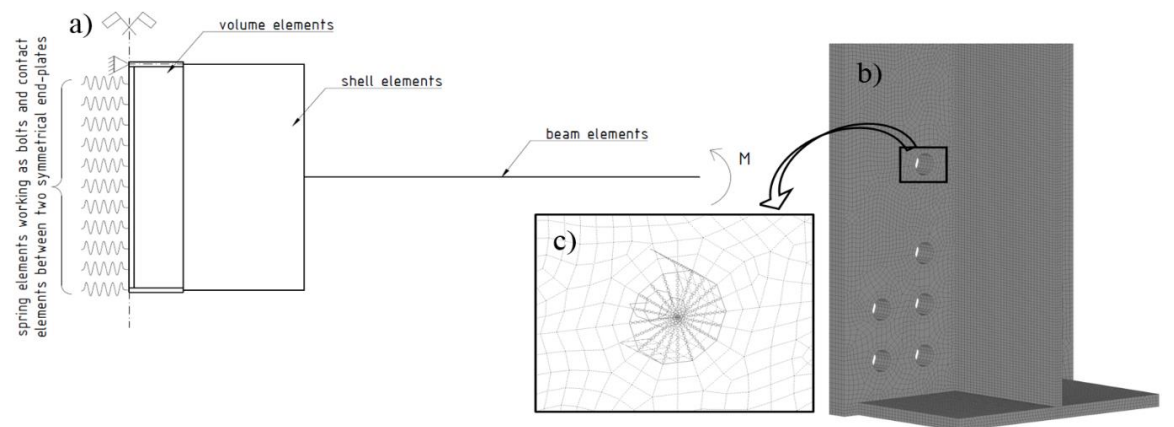

Figure 2. The FEM model of the end-plate connection: a) scheme of the numerical model of the joint, b) the detail of the joint with volume elements only, c) the connection between spring (the bolt) and shell elements - kinematic constraints

Constraints have been determined to place the load with a point bending moment in the end of the girder. Nodes, which are located in the end-plate, in the place of the theoretical compression center (the top flange axis) were fixed. The bolts and contact between the end-plates have been modeled by nonlinear one direction spring elements. The edges of the holes, with a $28 \mathrm{~mm}$ radius, have been made as rigid parts. This action has been made to exclude numerical problems with high FEM plastic strain concentrations on the hole's edges. 
The calculations have been made according to a nonlinear analysis. The characteristics of the material the bolts are made of (one type of spring elements) have been set on basis of the stressstrain relationship, specified for 10.9 class bolts in tensioning by the tightening of a nut [3]. On the basis of the given data, the offset yield strength $(0.2 \%$ offset from the linear portion of the stressstrain curve) has been set as $R_{0,2}=830 \mathrm{MPa}$. Furthermore, on the same basis, the ultimate strains in tension have been calculated as $\varepsilon_{g r}=1 \%$. In the model these values have been used to create a perfectly elastic plastic material for the bolts. Additionally, the material law has been expanded with the bolt strain limit. Finally, the methods used and assumptions made were proven through evaluation with the FEM model analyzed in [8]. The forces in bolts were consistent.

\section{IDENTIFICATION OF THE WORK OF THE JOINT - THE VOLUME MODEL}

Establishing a basis for estimating the bending resistance of an end-plate joint is determining the moment which ultimately destroys a joint due to bolt fracture and/or full plasticizing of plates. For this purpose a nonlinear, increment analysis has been done. Through this method we have investigated how forces are changing in individual bolt rows in relation to the value of the inserted bending moment. Simultaneously, areas of plasticizing in the end-plate and the web have been controlled. The results in the form of the force-bending moment relationship have been shown in the Fig. 3. Calculations have been presented for the range from $1250 \mathrm{kNm}$ to $3750 \mathrm{kNm}$. Markings on the chart have been used in accordance to the convention proposed in [3] (Fig. 3). In the chart, the designed bending moments have been stated by vertical lines. The design bolt tension resistance according to [1] has been previously identified as $379 \mathrm{kN}$.
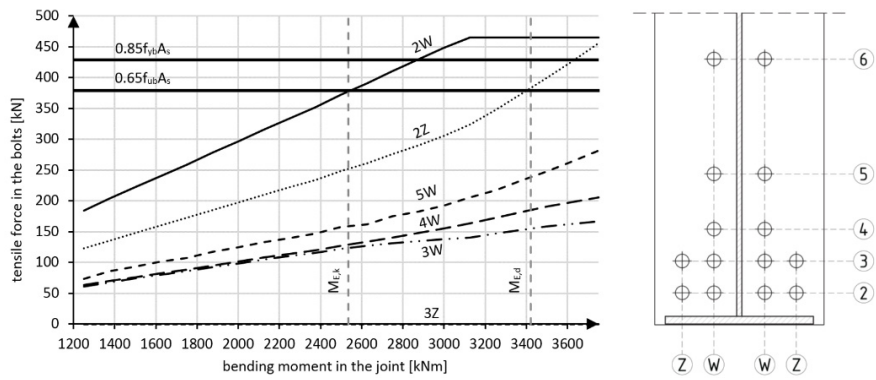

Figure 3. The relationship between a bending moment and forces in the bolts according to the volume model (left) and the convention marking bolts in an end-plate joint according to [3] (right) 
Analysis shows that the first signs of plasticization appear in the end-plate between the holes for the bolts, if the bending moment is equal to $M=1875 \mathrm{kNm}$ (Fig. $4 \mathrm{a}$ ). For the bending moment equal to $M=2375 \mathrm{kNm}$ (Fig. 4b) the web of the girder begins to plasticize. If the bending moment is equal to $M=3125 \mathrm{kNm}$ (Fig. 4c) the end-plate in connection with the web begins plasticize. Simultaneously, the most strenuous bolts achieve the offset yielding strength (Fig. 3). On the basis of these results, it can be concluded that plasticizing in the end-plates does not cause significant changes in chart character. The changes appear when most loaded bolts achieve the offset yield strength (bolt no 2W, Fig. 3).

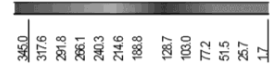

a)

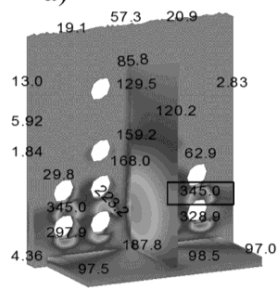

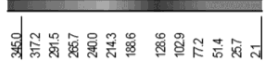

b)

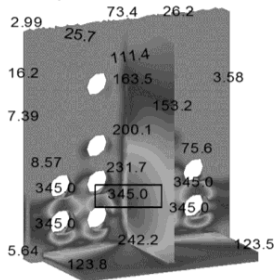

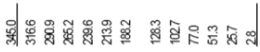

c)

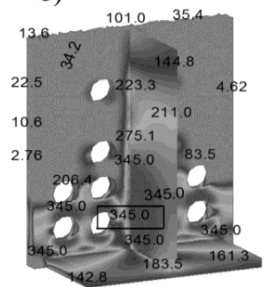

Figure 4. Von Mises stresses in bottom rt of the end-plate joint - the volume model: a) M=1875kNm,

b) $\mathrm{M}=2375 \mathrm{kNm}$ c) $\mathrm{M}=3125 \mathrm{kNm}[\mathrm{MPa}]$

A volume model containing volume elements, with an assumption of good discretization, is the most accurate from the FEM point of view. However, the thin shell FEM model can be an attractive alternative in technical investigations of atypical end-plate joints.

\section{THE COMPARISON OF RESULTS FROM VOLUME AND SHELL MODELS}

Volume elements have been changed to shell elements, and the analysis has been done as in the primary model. The range of increment has been expanded from $100 \mathrm{kN}$ to the first bolt fracture. The forces in the bolts have been compared between the volume and the shell model (Fig. 5). The results from both models seem to be convergent, and thus further analysis has been carried out with the shell model. 


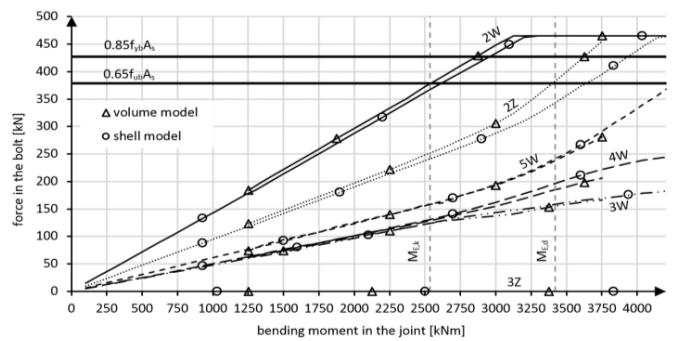

Figure 5. The comparison of forces in the bolts for the volume and shell models

In the shell model plasticization in the plates have been controlled also. The first sign of plasticizing, has appeared between holes, for the bending moment $M=1400 \mathrm{kNm}$ (Fig. 6a). For $M=2500 \mathrm{kNm}$ (Fig. 6b) the web and the end-plate in the connection with the web have been plasticized. The offset yielding strength has been reached by the first bolt for $M=3300 \mathrm{kNm}$ (Fig. 6c). Differences in the results between the models are due to the edge connections between the end-plate and the web, which causes faster local plasticization. A comparison of the forces (Fig. 5) shows that local plasticization does not significantly affect the force distribution.

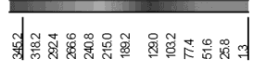

a)

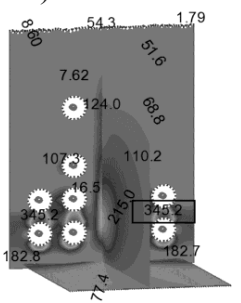

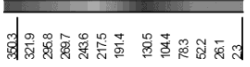

b)

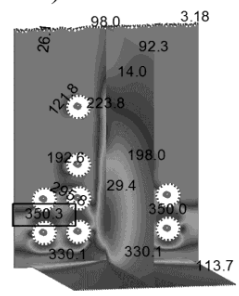

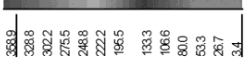

c)

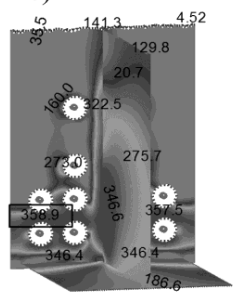

Figure 6. Von Mises stresses in bottom part of the end-plate joint - the shell model: a) M=1400kNm,

b) $\mathrm{M}=2500 \mathrm{kNm}$, c) $\mathrm{M}=3300 \mathrm{kNm}[\mathrm{MPa}]$

In the previous analysis, a perfect quality of assembly of a joint and an ideal adjacency between end-plates have been set and the extremely adverse situation with gaps between end-plates was analyzed. An additional model without the possibility of contact between end-plates has been constructed. The relationship of the force-bending moment has been determined (Fig. 7). The character of the deformation is shown in Fig. 8. 


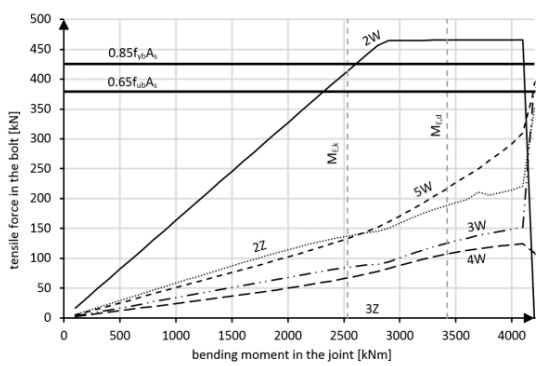

Figure 7. Forces in the bolts related to the bending moment - the shell model without contact

The most deformed part of the end-plate displaces in the direction 'to joint' only about $0.5 \mathrm{~mm}$ for bending moment $M=2300 \mathrm{kNm}$ (Fig. 8). In consequence, the model without contact has been specified as measurable.

a)

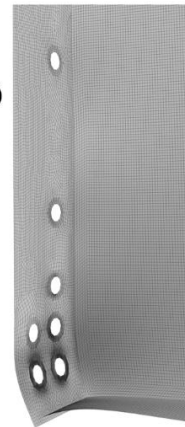

b)

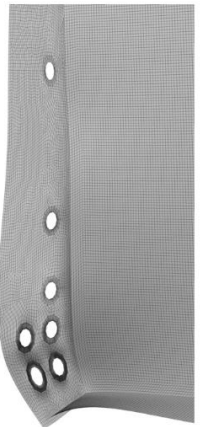

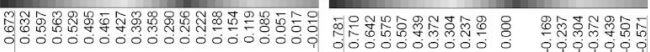

c)

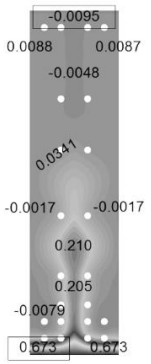

d)

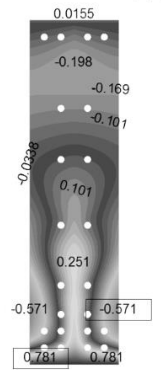

Figure 8. Details of the end-plate deformation in the model: a) with contact, b) without contact. Values of nodal displacements [mm] in the end-plate for bending moment $\mathrm{M}=2800 \mathrm{kNm}$ in the model: c) with contact (no gap between end-plates), d) without contact (a gap between end-plates).

\section{DETERMINATION OF JOINT BENDING RESISTANCE ON THE BASIS OF NUMERICAL CALCULATIONS}

To summarize, it can be deduced that the bending resistance specified with the shell model without contact shows the lowest resistance of the joint. This is because in the shell model the plasticizing of plates appears earlier than in the volume model, but forces on the bolts have similar distribution in all samples. Furthermore, if end-plate thickness satisfies the minimum thickness requirements (Eq. (3.1)) from [1] it implies that failure of a joint will happen due to the fracture of 
bolts; our analysis confirms this research. Thus, the bending resistance of end-plate joints can be expressed by the value of the bending moment which is in direct relationship with the design bolt resistance. Using the chart in Fig. 7, the corresponding bending moment can be determined as such. When comparing this value with the bending moment from the current design, it can be presented as a ratio in Eq. (8.1).

$$
\frac{M_{E d}}{M_{j, R d}}=\frac{3421}{2300}=1.49>1
$$

It seems that when considering unfavorable but possible conditions, the designed end-plate connections do not fulfill the desired requirements.

\section{SUMMARY}

There is no doubt that determining end-plate beam splice bending resistance should be made with appropriate care, due to the complexity and responsibility of that aspect of construction. In the case of the end-plate in particular, attention should be paid to the conditions regarding minimum end-plate thickness, the usage of bolts with proper strength, and the usage of the bolt locations tested in a given joint. Additionally, for joints connecting elements with slender webs, it should be checked which bolts participate in the transfer of loads in the most decisive way.

Calculations according to the codes use limited theoretical models. FEM analysis ensures a more realistic distribution of forces in bolts. This can be obtained thanks to the space model which takes into account the complex stiffness of every component of the joint when evaluating internal forces. The simplified thin shell model gives good predictions of forces in bolts, however it cannot be used for studying local effects in connections.

Included in the codes are procedures and requirements which have been specified on the basis of precise analysis and research. Thus, uncritical modifications of code procedures are forbidden. Assessments of joints constructed without respect to code requirements provide incorrect joint resistance information. 


\section{REFERENCES}

1. PN-90/B-03200:1990 Konstrukcje stalowe. Obliczenia statyczne i projektowanie.

2. PN-EN 1993-1-8:2006 Projektowanie konstrukcji stalowych. Projektowanie węzłów.

3. J. Bródka, A. Kozłowski and others; Projektowanie i obliczanie połączeń i węzłów konstrukcji stalowych.; Vol. I and II., Polskie Wydawnictwo Techniczne, Poland, 2013

4. W. Śliwka; Badania doczołowych styków sprężanych śrubami o wysokiej wytrzymałości poddanych obciążeniu rozciągającemu wzdłuż osi śrub. Praca badawcza 07.1/13.3.5N.; COBPKM "Mostostal", Warsaw, Poland, 1979

5. J. Augustyn, J. Łaguna, W. Śliwka; Charge limite des assemblages par boulons HR et plaque d'extremité sollicités en traction ou en flexion. - Construction Métallique Nr. 2-1982

6. A. Biegus; Połączenia śrubowe; Warsaw - Wroclaw, Wydawnictwo Naukowe PWN, Poland, 1997

7. W. Kawecki and others; The abridged method for manual design of rigid end-plate preloaded connections according to PN-EN 1993-1-8; Inżynieria i Budownictwo, 7/2009, p. 393-398

8. P. Kawecki, J. Łaguna, A. Kozłowski; Analysis of the moment resistance of i-beam end plate connection with multiple bolt rows; in Polish; Czasopismo Inżynierii Lądowej, Środowiska i Architektury, z. 60, nr 2, p. 117 136, Oficyna Wydawnicza Politechniki Rzeszowskiej, 2013 


\section{LIST OF FIGURES AND TABLES:}

Fig. 1. The analyzed structure: a) view on the roof of the Blanik's hall during construction, b) the cross section of the end-plate joint (own archive)

Rys. 1. Analizowna konstrukcja a) widok na dach hali Blanika w trakcie budowy, b) przekrój poprzeczny węzła (archiwa własne)

Fig. 2. The numerical model of the end-plate connection: a) scheme of the numerical model of the joint, b) the detail of the joint with volume elements only, c) the connection between spring (the bolt) and shell elements - kinematic constraints Rys. 2. Model numeryczny połączenia doczołowego a) schemat modelu numerycznego połączenia, b) szczegół węzła w części bryłowej, c) połączenie sprężyny (śruby) z elementami powłokowymi powiązania kinematyczne

Fig. 3. The relationship between a bending moment and a forces in the bolts according to the volume model (left) and the convention marking bolts in an end-plate joint according to [3] (right)

Rys. 3. Zależność moment zginający - siła w śrubie w modelu bryłowym (lewo) i konwencja oznaczenia śrub w styku według [3] (prawo)

Fig 4. Von Mises stresses in bottom part of the end-plate joint - the volume model: a) M=1875kNm,

b) $\mathrm{M}=2375 \mathrm{kNm}$ c) $\mathrm{M}=3125 \mathrm{kNm}[\mathrm{MPa}]$

Rys. 4. Naprężenia HMH w dolnej cześci połączenia doczołowego - model bryłowy: a) M=1875kNm, b) $\mathrm{M}=2375 \mathrm{kNm}$ c) $\mathrm{M}=3125 \mathrm{kNm}[\mathrm{MPa}]$

Fig. 5. The comparison of forces in the bolts for the volume and the shell models

Rys. 5. Porównanie sił w śrubach z modelu brylowego i powłokowego

Fig. 6. Von Mises stresses in bottom part of the end-plate joint - the shell model: a) M=1400kNm, b) $\mathrm{M}=2500 \mathrm{kNm}$, c) $\mathrm{M}=3300 \mathrm{kNm}[\mathrm{MPa}]$

Rys. 6. Naprężenia HMH w dolnej części połączenia doczołowego - model powłokowy: : a)

$\mathrm{M}=1400 \mathrm{kNm}, \mathrm{b}) \mathrm{M}=2500 \mathrm{kNm}$, c) $\mathrm{M}=3300 \mathrm{kNm}$ [MPa]

Fig. 7. Forces in the bolts related to the bending moment - the shell model without contact

Rys. 7. Siły w śrubach w odniesieniu do momentu zginającego - model powłokowy bez kontaktu

Fig. 8. Character of the end-plate deformation in the model: a) with contact, b) without contact. Values of nodal displacements [mm] in the end-plate for bending moment $\mathrm{M}=2800 \mathrm{kNm}$ in the model: $\mathrm{c}$ ) with contact (no gap between end-plates), d) without contact (a gap between end-plates).

Rys. 8. Charakter deformacji [mm] blachy czołowej w modelu: a) z kontaktem, b) bez kontaktu. Przemieszczenia węzłowe w blasze czołowej dla momentu zginającego $\mathrm{M}=2800 \mathrm{kNm}$ w modelu: c) z kontaktem (brak odstępu między blachami czołowymi), d) bez kontaktu (odstęp między blachami czołowymi). 


\section{NOŚNOŚĆ NA ZGINANIE POŁĄCZENIA DOCZOLOWEGO ELEMENTÓW DWUTEOTYWCH DŹWIGARA DACHU, STUDIUM PRZYPADKU}

Slowa kluczowe: niespreżone połaczenia doczolowe, połaczenie zginane, analiza MES, dach hali sportowej

\section{STRESZCZENIE:}

Wyznaczenie nośności styków doczołowych powinno być przeprowadzone z należytą dbałością, ze względu na wysoki stopień skomplikowania i odpowiedzialność tego elementu konstrukcyjnego. W przypadku szacowania nośności zginanych połączeń doczołowych zgodnie z normą PN-90/B-03200 należy przede wszystkim zwrócić uwagę na warunek minimalnej grubości blachy czołowej, użycie śrub o odpowiedniej, ujętej w procedurze wytrzymałości oraz stosowanie rozkładów śrub w węźle, które zostały przebadane i uznane za właściwe. Metoda składnikowa zaproponowana w PN-EN 1993-1-8 pozwala uwzględnić trzy rożne modele zniszczenia styku i wykorzystuje bardziej złożone modele matematyczne, lecz uzyskany rezultat wciąż należy traktować jako przybliżony. Dodatkowo, w przypadku obu normatywów, dla połączeń elementów o smukłych środnikach (jak to miało miejsce w opracowanym studium przypadku (rys. 1), należy dokonać sprawdzenia, które ze śrub w sposób decydujący biorą udział przy przenoszeniu momentu zginającego. Procedury ujęte w obu normach nie rozwiązują wprost tego problemu.
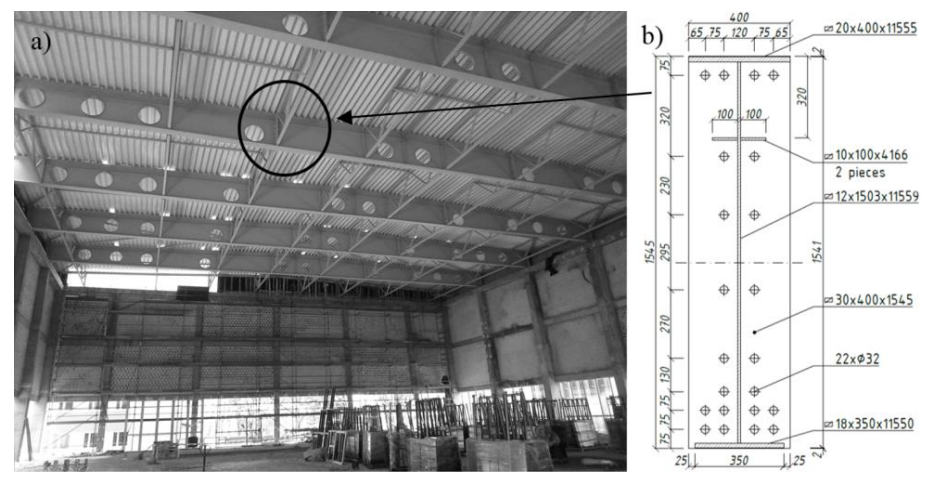

Rys. 1. Analizowane połączenie: a) widok dachu Hali Blanika w czasie budowy z zaznaczoną lokalizacją węzła, b) przekrój poprzeczny przez węzeł

Zawarte w normach procedury i wymagania dotyczące wymiarowania zginanych styków doczołowych zostały wyznaczone na bazie ściśle określonych analiz i badań. Z tego powodu niedozwolone jest ich bezkrytyczne modyfikowanie. $Z$ drugiej strony, przeprowadzona w sposób standardowy ocena styku zaprojekowanego i wykonanego bez uwzględnienia wszystkich wytycznych normowych, prowadzi do uzyskania nierealnej nośności węzła.

Obliczenia nośności przeprowadzone zgodnie z normami, bazują na właściwych, ale ograniczonych do grupy przypadków modelach teoretycznych. Analiza MES pozwala uzyskać bliższe rzeczywistości rozkłady sił w śrubach (rys. 2). Jest to możliwe do osiągnięcia dzięki modelowi przestrzennemu, który uwzględnia zróżnicowaną sztywność elementów styku przy wyznaczaniu sił wewnętrznych. Dodatkowo dzięki zastosowaniu w analizie nieliniowości materiałowej uwzględnione są również redystrybucje sił wywołane uplastycznieniem blach w połączeniu. W przypadku 
analizy z wykorzystaniem symetrii węzła znaczący wpływ na uzyskane wyniki ma także potencjalny kontakt pomiędzy blachami czołowymi. Jego uwzględnienie w znaczny sposób zwiększa nośność przez ograniczenie przemieszczeń blach w kierunku do węzła. Należy jednak zwrócić uwagę na możliwy odstęp pomiędzy blachami czołowymi w połączeniu doczołowym niesprężonym. Może on wynikać z niedokładności montażu czy też imperfekcji geometrycznej elementu. Niebagatelne znaczenie na rezultaty analizy MES ma rodzaj zastosowanych w modelu elementów skończonych. Modele wykorzystujące bryłowe elementy skończone o 8 węzłach pozwalają na analizę naprężeń w blachach w większym zakresie niż w przypadku 4 węzłowych elementów powłokowych. Odwzorowanie grubości blach za pomocą elementów skończonych zwiększa dokładność uzyskiwanych rezultatów w strefach uplastycznienia i w strefach zmian geometrii. Jednakże jeśli wyłącznym celem projektanta jest wyznaczenie sił w poszczególnych śrubach, to oba modele pozwalają otrzymać zbliżone do siebie rezultaty przy znacznie łatwiejszej generacji modelu oraz mniej kosztownej czasowo analizie w przypadku zastosowania elementów powłokowych.
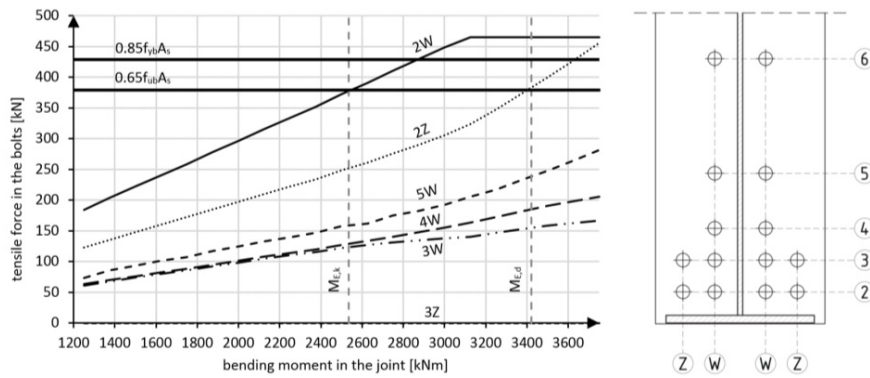

Rys. 2. Wykres zależności moment zginający - siły w śrubach na podstawie modelu bryłowego (lewo) wraz z konwencją oznakowania śrub w węźle (prawo) 